\title{
CHILD WELFARE: A REVIEW BASED ON SOCIAL DEVELOPMENT PERSPECTIVE
}

\author{
Ishita Kapur \\ Masters in Social Work, Jamia Millia Islamia, New Delhi
}

Article DOI: https://doi.org/10.36713/epra7527

DOI No: 10.36713/epra7527

\begin{abstract}
The article explains why enhancing educational equity and minimising school failure are cost-effective, especially in light of the current economic crisis. Children are harmed by inequitable education policies and practices, which also impede economic and social progress. The importance of school in the lives of children is discussed. It is argued that school has the potential to be an ally for children, a provider of basic protection, a capacity builder, a safe base from which to explore oneself and the world, an integrator into community and culture, a gateway to opportunities, and a resource for parents and communities. It emphasises the importance of investing early in all children, particularly those from underprivileged backgrounds, and supporting them through upper secondary school, particularly in times of fiscal difficulties. Reduced school dropout benefits both society and individuals. It can also help with economic development and social development. Indeed, the most successful education systems in the world are those that combine quality with equity. In education, equity means that personal or societal conditions, such as gender, ethnic origin, or family background, are not impediments to realising educational potential, and that all students attain a basic minimum level of abilities.
\end{abstract}

KEY WORDS; social work, school, children, child and family social work

\section{INTRODUCTION}

Education systems that mix equity and excellence have the best results. They provide all children with the opportunity to receive a highquality education. A child's failure in school has long-term consequences. A child who drops out of school without completing upper secondary education or possessing the necessary abilities has fewer opportunities in life. The same child is also less likely to pursue additional education and is less capable of fully participating in civic and democratic components of modern society. Lower starting and lifetime incomes, more difficulty adapting to fast changing knowledge-based economies, and higher unemployment risks are all signs of this. National educational policies appear to receive little attention in social work education or research. Educational failure also has a high societal cost. People with a low level of education impede an economy's ability to create, grow, and innovate. School failure harms social cohesion and mobility, as well as imposing additional expenses on government budgets to deal with the repercussions - higher public health and social assistance spending, as well as increased criminality, to name a few. This article seeks to examine common neglect of school as a powerful institution in the social development and protection of children worldwide. Various roles that schools can play in young people's social development are conceptualised and discussed. Furthermore, the specific contribution that schools can make to vulnerable groups of children is taken into account.

Children's life chances are strongly influenced by the quality of their education. Schools aim at providing children with knowledge, skills and interpersonal competences required for their development, adult life and contributions to economy and society. Schools can offer learning experiences that a child may not obtain at home, particularly if he or she is living in a disadvantaged environment (Heckman, 2011). However despite efforts by governments to provide high quality education, significant disparities in educational outcomes continue to exist. A large number of students fail to obtain a minimum level of education, jeopardising their own future and the progress of their society (Publishing, 2012). 
The arguments in my paper are derived from my reading of literature:

1. A school must stimulate curiosity in the young, impressionable minds and equip them with tools to be better human beings (Sharma, 2021).

2. School must be seen as a potentially key preventive and protective resource for children experiencing social adversity, since the positive effects of school experience seem most evident or potent among students who are vulnerable (Rutter, 2009).

3. Teachers are the professionals who have the most contact with children and thus must be understood by other child-focused professionals.

4. Resources to assist children and families experiencing adversity are difficult to generate, in terms of both finding additional resources and avoiding stigma. Strengths perspective reminds us to look for resources in unlikely places. Even the harsh local environment may also be 'a lush topography of resources' (Saleebey, 2006).

5. Schools also must be involved in working to prevent maltreatment from ever occurring at all. Schools are in a unique position to address this problem by virtue of the staff's training and expertise, the school's position in the community, and the availability of physical facilities (Crosson-Tower, 2003).

6. The fact that some schools or teachers may fail due to a lack of resources, policy, governance, support, training, or the socioeconomic foundation of their host community does not preclude schools from succeeding in the face of adversity. Any disillusionment with schools or teachers resulting from negative personal or professional experiences with schools, or even philosophical reservations about schooling, should not obscure the school's normalising potential as a social institution, especially for children who do not have other non-stigmatizing sources of support, social inclusion, and encouragement in their lives.

\section{THE VALUE OF SCHOOLING IN CHILD WELFARE}

In this section, it is argued that schools play, or have the potential to play, a number of important roles in the social development of their students under the right conditions. These roles are classified under several headings.

Strengthen School leadership: School leadership is the starting point for the transformation of low performing disadvantaged schools but often, school leaders are not well selected, prepared or supported to exercise their roles in these schools. To strengthen their capacity, school leadership preparation programmes should provide both general expertise and specialised knowledge to handle the challenges of these schools (Publishing, 2012). Findings from a recent British study of teenagers' experiences of social work and related services suggest that, for some young social work clients at least, teachers may be preferred to social workers as confidants (Triseliotis, 2011).

School with efficient teachers: The educator has a vital role in identifying, reporting, and preventing child abuse and neglect. There are many reasons why educators are so vital in identifying, treating, and preventing child maltreatment. First, they have close and consistent contact with children. Second, educators have a professional and legally mandated responsibility for reporting suspected maltreatment. Third, school personnel have a unique opportunity to advocate for children, as well as provide programs and services that can help children and strengthen families (Crosson-Tower, 2003). It can be concluded that school welfare provision will positively influence teacher performance if teachers are reciprocally committed to work while at the same time administrators meet teachers varied needs. This argument is in support of Vroom's Expectancy Theory as the theoretical lens for the study. The theory emphasizes that people join organizations with expectations about fulfilment of their needs and motivations. In the process, they also have to satisfy the organization's goals (Lunenburg, 2011). The needs and motivations represent people's social welfare (Naluwemba Frances, 2016).

School with a facilitative learning environment: Appearance, behaviour, performance, time-keeping, parental contact, and travel to and from school can all provide clues to alert teachers about the child's social life both inside and outside the school gates. When the school's threshold of concern is crossed, vigilance and action on the part of the school can initiate the process of assistance. Schools can advocate for students to address any difficulties they may be experiencing as victims or as risk takers. Schools lend their voice to a child in need (O'Moore, 2007).

School with supportive structures for children: Schools provide children with opportunities to build their self-esteem (Brooks, 1994). High expectations of their students imply that the school believe in the innate capacity of the young person. Such high expectations can help to promote resilience (Benard, 1991). School structures, resources and practices also matter greatly. The way learning is delivered, extracurricular activities, discipline, relations with peers 
and teachers and some pedagogic practices have a strong impact on students' learning, motivation and sense of belonging (Publishing, 2012). In the case of risk behaviours such as drug abuse, there is some evidence that well-constructed school-based life skills training programmes may have an impact in reducing subsequent drug use (Gilbert J. Botvin, 1995). It seems that positive school experience may also foster in quite a central way a sense of selfefficacy. In the long run, the effects of school may be less to what children are actually taught than to the school's impact on children's attitudes to learning (Rutter, 2009).

School as a place for quality education of children: School is a place for a child experiencing typical developmental possibilities to acquire confidence and social belonging, to practise adult identities, and to investigate oneself and the environment. The supportive school, in the view of a Dutch observer 'presents a secure space for students who experience being respected as persons that stimulates their intellectual and emotional possibilities' (Katz, 2003). Within a positive school ethos, teachers can come to recognize the classroom and the school as 'a symbolic and sanctuary for the vulnerable child' (Crosson-Tower, 2003).

School with a link to parents and communities: Disadvantaged parents tend to be less involved in their children's schooling, for multiple economic and social reasons. Engaged parents encourage more positive attitudes towards school, improve homework habits, reduce absenteeism, disengagement and dropout and enhance academic achievement. Policies need to be designed to ensure that disadvantaged schools prioritise their links with parents and communities, building the capacity to: a) Improve and diversify communication strategies to align school and parental efforts. The more effective strategies target parents who are more difficult to reach and provide them with clear guidelines on how to best support their children. b) Identify and encourage individuals from the same communities to mentor students from disadvantaged schools and support their learning. This can be particularly effective in improving schooling outcomes. Links can also be built with local stakeholders, such as the business community (Publishing, 2012).

School as a resource to parents and communities: Parents and community members as supporters and advocates for the education of their children are facilitated through site-based school restructuring. Restructuring schools to create parent and community partnerships with schools focuses on organizational structure. Changing activities; creating new relationships between parents, families, communities, and schools; and implementing innovative strategies are ways that schools can restructure to facilitate parent and community involvement in this role. Parents and community members as participants in the education of all children incorporate a broader vision in the partnership between schools and the populations they serve. District wide programs provide the vehicle for parents and community members to be involved in roles that reach beyond the immediate impact of an individual child to the impact on all children in the district (Barry Rutherford, 1995).

\section{THE ROLE OF SCHOOLS TO TACKLE ISSUES THAT HINDER WELFARE OF CHILDREN}

We can never equalise all of the factors that influence achievement and personal success. However, we can invest wisely to address disparities that cause large and persistent problems that endanger our children's well-being. Across socioeconomic groups, gaps in capabilities that play important roles in determining diverse adult outcomes emerge early. The gaps begin before formal schooling and continue throughout childhood and into adulthood. Resolving problems caused by gaps is more expensive than preventing them in the first place.

\section{Help Children who need care and supervision}

In their study of teenagers with social workers, Triseliotis et al. (1995) found that 'a view of self and comparatively favourable educational progress seemed to be important factors in negotiating the problem' (Triseliotis, Teenagers and the Social Work Services, 2011).

There is evidence that school may influence outcomes for children. A Danish follow-up study of adults in care found that school experiences have been an important factor for those who had done reasonably well despite adversity. One study has found that the prospects for placement stability were enhanced where the child did not change school when moving into the foster home (Cleaver, 2010).

\section{Assist children who are at risk of becoming delinquent}

Children showing persistent disruptive behaviour are likely to become child delinquents and, in turn, child delinquents are likely to become serious, violent, or chronic juvenile offenders. Understanding the early emergence of problem behaviours may help in the creation of earlier, effective interventions for the prevention of child delinquency (Rolf Loeber, 2003).

A review of effective approaches to prevention found that good quality programmes and school environment and practices had a bearing on the path 
which a vulnerable youngster would follow (Yoshikawa, 1994). Studies addressing school influences on antisocial behaviour have consistently shown that poor academic performance is related to child behaviour problems and to the prevalence, onset, and seriousness of delinquency (Rolf Loeber, 2003).

\section{Children who are facing emotional or behavioural issues}

Schools may also influence favourably the level of emotional problems. Research findings suggest that the school factors which promote positive behaviour include: 'high expectations for work and behaviour, models of behaviour, a respect for children, opportunities for children to be involved in the school, encouragement of good behaviour, pleasant working conditions, good teacher-child relationships (Cox, 2018). Of all known interventions to reduce juvenile delinquency, preventive interventions that focus on child delinquency will probably take the largest "bite" out of crime. Specifically, these efforts should be directed first at the prevention of persistent disruptive behaviour in children in general; second, at the prevention of child delinquency, particularly among disruptive children; and third, at the prevention of serious and violent juvenile offending, particularly among child delinquents (Rolf Loeber, 2003).

\section{Children of divorced parents}

American researchers have found that attention from teachers were associated with positive adjustment by the child after parental divorce (Cox, 2018). In one large American study it was found that students who had experienced parental divorce benefited from an authoritative school climate which 'provided an organized, environment with clearly defined enforced standards, expectations for appropriately mature, responsible behaviour. These benefits of the school were marked for children who had experienced parental divorce, high levels of conflict, or high levels of stressful life events' (Hetherington, 1993).

\section{Children who have been abused or neglected}

Relationships with teachers may help people compensate for lack of supportive relationships in their lives (J.Galbo, 1986). The teacher may be able, for instance, help child recover from or cope with a stressful experience such as sexual abuse by gradually helping the child to rebuild self- confidence coping with stress (Maggie Robson, 1995).

The protection of children is not only an individual issue, but a community concern as well. Educators are an integral part of the community and, as such, can lead and be involved in community efforts to combat child maltreatment (CrossonTower, 2003).

\section{Children from economically disadvantaged families}

School experiences may serve as some of the worst effects of socio-economic disadvantage. The interest of teachers and other school staff may prove very beneficial. Researchers in one study found that 'for students who experience one or more conditions of disadvantage, support received from school was associated with positive academic outcomes' (DuBois DL, 1994).

\section{CONSEQUENCES FOR CHILD AND FAMILY SOCIAL WORK}

While child protection is likely to have raised the profile of teachers and schools in the minds of many social workers, it is critical that they recognise that teachers and schools play a larger role in the social development of children than a brief cameo in the opening scenes of any child protection drama.

If the task is to broaden our appreciation of the role of schools and teachers, there is a parallel need to expand our conception of what social work can contribute. The challenge is to develop context and appropriate models of social work in support of the tasks of teachers, children, parents and community (Openshaw, 2008). Because social workers and teachers are unable to assist children in need, alternative views of what is possible become even more crucial. Otherwise, many countries' children, parents, professions, and citizens may succumb to the "inevitability" of the status quo. Where they occur, poorly run schools, oppressive behaviour by teachers or students, poor interaction with parents, and poor relations amongst groups of professionals are not unavoidable. They result from policy, governance, and resource allocation decisions made by those in positions of authority. Challenging the harmful consequences of such decisions necessitates the involvement of a variety of stakeholders in the educational system, including, as this article argues, social workers and social services. Now, specific ways in which social workers might assist in the development of new possibilities are being investigated;

\section{The provision of counseling for children}

School counselors provide counseling and guidance for students. They assist students with academic and personal problems to help them succeed in school. Many middle and high school counselors also help students plan their schedule of classes. Counselors for students in the higher grades help students plan for careers and higher education (Openshaw, 2008). 
In particular, they must recognize the value of education and the school for youngsters in terms of their educational and social development and conversely the risks posed by educational failure (Milner, 2016).

Matters such as homework, adjustment to new schools and the other paraphernalia of school life require more attention. Two specific forms of intervention may be worthy of social work and support: helping children with reading difficulties, and after school study support schemes (Menmuir, 2006).

\section{Rationale behind involving teachers for child welfare}

The importance of the teacher's professional involvement in the welfare of children must be recognised by social workers. Engaging effectively with teachers and schools must also be considered a vital professional responsibility in child-centred social work. It is critical for non-teachers to understand the hard realities of life in the classroom while engaging with them and forming professional partnerships with them. Non-school professionals must be aware of the cost to teachers of intimate exposure to the raw facts of abuse or other difficulties in children's lives, as well as the personal and professional ramifications of such exposure (Kelly, 1980).

In the absence of proper specialised training or support, the thought of a lifetime of teaching in a community trapped in persistent poverty can deplete morale and tolerance. Teachers may feel compelled to use tactics that are ultimately ineffective in terms of student motivation and achievement, as well as the teachers' own pleasure. However, it is a disservice to children to expect or claim too much for the role of teachers at times of crisis in a child's life. The problems at home may not be known to teachers or they may be too great for teachers to be able to engage with them (Kelly, 1980).

Teachers who are well equipped with knowledge, skills and positive attitudes (Walsh, Rassafiani, Mathews, Farrell, \& Butler, 2010) can respond and assist maltreated children, including those who have been multiply victimized, by enhancing their learning potential and assuring their future safety. The second reason for locating child protection in pre-service teacher education relates to teachers' legal duties to report child abuse and neglect (Kerryann Walsh, 2011).

\section{Collaboration with the rest of the school and community}

Social workers and their organisations must acknowledge social work as a discipline with a knowledge base and level of expertise relevant to (1) the development of individual schools and the school system as a whole, and (2) the school's deeper integration into community, professional, and children's services networks. School social workers assist children so they can be successful in school. The goal of school social work should be to give all children the opportunity and resources to help them succeed academically and socially in a safe and healthy school environment.

Social work in a public school setting plays a vital role in developing students and linking them to the resources and support necessary to maximize their potential in the educational process (Julie O'Donnell Ph.D., 1995). School social work is one of the most rewarding and interesting areas of social work practice. School social workers can have a life changing impact on their young clients in a way that those who work with adults rarely experience (Openshaw, 2008). Therefore, social workers and the organisations that employ them must be at the forefront of initiatives aimed at improving communities, schools, and, ultimately, the environment in which children grow up.

\section{Integration of Schools with social work}

As previously stated, social workers can only properly respond to the aforementioned exhortations if they are supported by suitable policies and resource allocation within each country's community services and educational systems. However, progress on this front requires a belief among child and family social workers that the school-social work link is part of their "core business." As a result, it appears critical that education and school concerns be prioritised considerably higher on the professional agenda of social work in terms of educational and training curriculum as well as professional supervision. Instead of seeing schools as a possible source of additional pressures and demands that cannot be met, social workers must be encouraged to see them as potentially effective allies in their work with children. Social workers must understand the consequences of (1) educational success or failure for their child clients, as well as (2) the larger social worth of school experience.

Collectively and individually, social workers in the child welfare field must see it as part of their professional mandate to participate in debates and policies affecting schools, with a particular focus on how well schools are resourced to work with vulnerable children and in high-risk communities. Their education must instil in them a sense of respect for the teacher's role and an understanding of the pressures that come with it. Individual teacher or school failures should not overshadow the good impact of schools and instructors on children's lives. It seems reasonable to hope that more satisfying professional roles for those involved, more integrated 
support for individual children, and new models of provision better geared to the social and developmental needs of vulnerable children and young people will result from such joint training and closer professional cooperation.

\section{REFERENCES}

1. Allen-Meares, P. (1994). Social Work Services in Schools: A National Study of Entry-Level Tasks. Oxford Academic.

2. Barry Rutherford, B. A. (1995). The Development and Implementation Of Parent and Community Involvement Programs. Studies of Education Reform: Parent and Community Involvement in Education. Retrieved from www2.ed.gov: https://www2.ed.gov/pubs/SER/ParentComm/cha p3.html

3. Benard, B. (1991, August). Fostering Resiliency in Kids: Protective Factors in the Family, School, and Community. Retrieved from files.eric.ed.gov: https://files.eric.ed.gov/fulltext/ED335781.pdf

4. Brooks, R. B. (1994). Children at risk: Fostering resilience and hope. American Journal of Orthopsychiatry.

5. Cleaver, D. B. (2010). Foster Home Breakdown. The Therapeutic Care Journal. Retrieved from https://thetcj.org/: https://thetcj.org/child-carehistory-policy/foster-home-breakdown-by-davidberridge-and-hedy-cleaver

6. Cox, A. (2018, January). Befriending Young Mothers. Retrieved from www.cambridge.org: https://www.cambridge.org/core/journals/thebritish-journal-of-

psychiatry/article/abs/befriending-youngmothers/360A0927863ACAB4AA4BD41BBF7F2 D40

7. Crosson-Tower, C. (2003). The Role of Educators in Preventing and Responding to Child Abuse and Neglect. Retrieved from www.childwelfare.gov:

https://www.childwelfare.gov/pubPDFs/educator .$p d f$

8. Dryfoos, J. G. (1994). Full service schools: A revolution in health and social services for children, youth, and families. San Francisco: Jossey-Bass. Wiley Online Library.

9. DuBois DL, F. R. (1994). Prospective investigation of the effects of socioeconomic disadvantage, life stress, and social support on early adolescent adjustment. Journal of Abnormal Psychology.

10. Gilbert J. Botvin, S. P. (1995). Drug Abuse Prevention with Multiethnic Youth. SAGE Publishing.

11. Heckman, J. J. (2011). The Economics of Inequality. Retrieved from files.eric.ed.gov: https://files.eric.ed.gov/fulltext/EJ920516.pdf

12. Hetherington, E. M. (1993). An overview of the Virginia Longitudinal Study of Divorce and Remarriage with a focus on early adolescence. SEMANTIC SCHOLAR.

13. J.Galbo, J. (1986). Adolescents' perceptions of significant adults: Implications for the Family, the School and Youth Serving Agencies. ScienceDirect.

14. Julie O'Donnell Ph.D., J. D. (1995). Preventing School Failure, Drug Use, and Delinquency among Low-Income Children: Long-Term Intervention in Elementary Schools. American Journal of Orthopsychiatry.

15. Katz, Y. J. (2003). The use of virtual reality three-dimensional simulation technology in nursery school teacher training for the understanding of children's cognitive perceptions. Springer Link.

16. Kelly, J. S. (1980). Surviving the breakup: How children and parents cope with divorce. SpringerLink.

17. Kerryann Walsh, L. L. (2011). Locating child protection in preservice teacher education. Australian Journal of Teacher Education , 33. Retrieved from files.eric.ed.gov: https://files.eric.ed.gov/fulltext/EJ936998.pdf

18. Maggie Robson, P. C. (1995). Helping Children Manage Stress. British Educational Research Journal.

19. Menmuir, $R$. (2006, August). Involving Residential Social Workers and Foster Carers in Reading with Young People in Their Care: the PRAISE reading project. Retrieved from www.tandfonline.com:

https://www.tandfonline.com/doi/abs/10.1080/03 05498940200306

20. Milner, E. B. (2016, February). Exclusion from School: Inter-Professional Issues for Policy and Practice. Retrieved from www.cambridge.org: https://www.cambridge.org/core/journals/journal -of-psychologists-and-counsellors-inschools/article/abs/exclusion-from-schoolinterprofessional-issues-for-policy-and-practicee-blyth-j-milner-eds-london-routledge1996/B00009D80595318A9EA3695E51731A9C

21. Naluwemba Frances, S. D. (2016). The interplay of school welfare provision and teacherperformance: The case of Ugandan secondary schools. Retrieved from files.eric.ed.gov: https://files.eric.ed.gov/fulltext/ED578105.pdf

22. O'Moore, M. (2007). Bullying Behaviour in Children and Adolescents in Ireland. Wiley Online Library.

23. Openshaw, L. (2008). The Role and Function of the School Social Worker. Social Work in Schools: Principles and Practice.

24. Publishing, O. (2012). Equity and Quality in Education. Retrieved from www.oecd.org: https://www.oecd.org/education/school/5029314 8.pdf

25. Rolf Loeber, D. P. (2003, May). Child Delinquency: Early Intervention and Prevention. Retrieved from www.ojp.gov: https://www.ojp.gov/pdffiles1/ojjdp/186162.pdf

26. Rutter, M. (2009, July 28). Pathways from Childhood to Adult Life; The Role of Schooling. Retrieved from www.tandfonline.com.

27. Saleebey, D. (2006). Strengths Perspectivein Social Work Practice, 4/e. Allyn \& Bacon/Longman. 
28. Sharma, D. (2021). The importance of school education in child development. Retrieved from www.educationworld.in:

https://www.educationworld.in/the-importance-

of-school-education-in-child-development/

29. Triseliotis, J. (2011, December). Teenagers and the Social Work Services. Retrieved from thetcj.org: https://thetcj.org/child-care-historypolicy/teenagers-and-the-social-work-servicesby-john-triseliotis

30. Triseliotis, J. (2011). Teenagers and the Social Work Services. The Therapeutic Care Journal.

31. Werner, E. E., \& Smith, R. S. (1992). Overcoming the Odds: High Risk Children from Birth to Adulthood. Retrieved from eric.ed.gov.

32. Yoshikawa, H. (1994, January). Prevention as cumulative protection: effects of early family support and education on chronic delinquency and its risks. Retrieved from pubmed.ncbi.nlm.nih.gov:

https://pubmed.ncbi.nlm.nih.gov/8310099/ 